\title{
STRATEGIC BEHAVIOR AND ORGANIZATIONAL STRUCTURE IN RELIGIONS *
}

\author{
Donald Wittman \\ Economics Department \\ University of California, Santa Cruz \\ California, 95064 \\ $831459-4445$ \\ wittman@ucsc.edu
}

April 20, 2012

\begin{abstract}
:
Religions are organized in a variety of ways. They may resemble an elected autocracy, a parliamentary democracy, or something akin to a monarchy, where heredity plays a primary role. This variation allows for a comparative study of their organization.

These differing power arrangements call for different types of strategic behavior in the fight for control over church doctrine and finance. And they also induce different institutional responses. I show where screening is highly institutionalized and when the age of a person may be an important strategic factor in choosing a leader. I am thus able to explain what otherwise would be very puzzling differences in the age of appointment across religions and within a particular religion, overtime.

In a nutshell, this paper is about politics and strategic behavior in the large (democracy versus autocracy) within the context of the small (religious institutions).
\end{abstract}

Keywords: religious organizations; autocracy; age; organizational structure; voting strategy

JEL CODES: D02, D72, Z12 


\section{STRATEGIC BEHAVIOR AND ORGANIZATIONAL STRUCTURE OF RELIGIONS}

Religions vary in how they structure political power. They may resemble an elected autocracy, a parliamentary democracy, or something akin to a monarchy, where heredity plays a primary role. These differing power arrangements call for different types of strategic behavior in the fight for control over church doctrine and finance. And they also induce different institutional responses. I show where screening is highly institutionalized and when the age of a person may be an important strategic factor in choosing a leader. For example, to tame the power of the elected-for-life autocrat vis-à-vis the electoral body, the electoral body will tend to choose older individuals as leaders so that the leader will not have enough time to amass even greater power. In contrast, when the leader chooses his successor, the leader would like to have influence long after he is gone. This is best accomplished by anointing a young person as leader. Secondary institutions that arise to mitigate the negative effects of the organizational structure may also affect the age when people are appointed to leadership positions. For example, there is always uncertainty about how a person will act, once appointed to a leadership position. This is of special concern when a person is appointed for life. In response, religions that do have life-long leadership positions will tend to screen potential leaders over a longer period of time than those religions where appointment is only for a term at a time so that this uncertainty is reduced. This additional screening time also accounts for leaders-for-life being older when first appointed than leaders elected to a term are. But when the present leader, rather than an electoral body, appoints his successor (typically a family member or close associate), the number of people screened is more limited and thus the time taken to screen is much shorter. Instead, the intervening time is used for grooming the leaderin-waiting for his future role.

This paper thus helps to explain what otherwise might be very puzzling differences in the age of appointment to the leadership position across religions. For example, the average 
age of appointment to prophet in the Church of Christ of the Latter Day Saints is nearly 73, appointment to pope of the Roman Catholic Church is nearly 65, appointment to Archbishop of Canterbury (Anglican Church) is 59, appointment to head of the Lutheran Missouri Synod is 52, and appointment to Rebbe of Chabad Lubavitch was just under 40 years old. The paper also explains changes within a church over time. For example, the theory predicts the dramatic shift in average age from 70 to 59 of the President of the Episcopal Church after 1926.

In more general perspective, this paper can be viewed as an illustration of how individual behavior mitigates certain institutional differences between organizations (e.g., the ostensible power difference between a leader elected for a term and an autocrat elected for life is reduced when older and less powerful leaders are elected to being autocrats). The paper can also be viewed as an illustration of how secondary institutions mitigate some of the problems inherent in the primary institution (e. g., choosing the wrong leader is more serious when the leader is elected for life than when the leader is elected for a term; so more screening occurs in the former). Although most of the paper treats the institutional structure for choosing leaders as a given, I also discuss when and where this structure is most subject to change.

There is a large body of social science research on religion, but, for the most part, the focus and/or methodology is only distantly related. Weber, who elsewhere discussed the nature of bureaucracies, showed little interest in the internal structure of religions in The Sociology of Religion. Rational actor models of religion have a prominent place in sociology (see for example, Young (1997), but most of this line of research has focused on religious competition (Finke, 1997) or why religions are strict (Iannaccone, 1988). Historians have written numerous books about the struggle for power within a particular religion. For example, see Penton, 1985, Reese, 1996, and Baumgartner, 2003, but their methodology is different from that employed here as they did not undertake a quantitative study over time and across denominations. Economists have devoted considerable attention to the internal structure of firms. The classic paper by Jensen and Meckling (1976) considers agency costs under different ownership structures. This paper considers agency costs in a different context (religion) with different means of control. Nearer in 
subject matter is work by Allen (1995) and Mao and Zech (2002). They show how doctrinal concerns put limits on the organizational form of the religion. Thus Roman Catholic doctrine implies a more hierarchical arrangement than Baptist doctrine. This paper takes a further step. It asks how structure (for example, whether the leader is elected for life or not) influences the degree of screening and the age of the leader. The field of political science has numerous works on democratic elections (see Downs, 1956, for the classic work in the field), dictatorships (Wintrobe, 1998) and forms of governance in between. Parliamentary democracy and autocracy roughly correspond to the organization of the Episcopal Church and the Catholic Church, respectively. But the focus of this political science literature is considerably different, concentrating on policy outcomes and coalition formation rather than on age. Nevertheless, I do employ a voting model to characterize church elections, and I will cover the related research when I introduce the formal model. Because I consider the issue of succession, previous work on the role of succession in autarchy is of relevance. The classic work on this subject is by Tullock (1987). Because he considers autocracies where power usurps formal rule (e.g., the Soviet Union, particularly in its earlier years), he asks different questions and provides more speculative answers than the present study, which treats the formal rules as being operative. Perhaps the closest work is by Giuriato (2009) in her study of the Catholic Church, which she views as an elected autocracy. But there the overlap ends and like all the other studies does not deal with age.

\section{Theory}

I consider a variety of religions with a number of structural differences, but I focus on the following key variables: (1) who chooses the new leader (the present leader or the assembly); (2) the length of the appointment (for life or for a fixed term length); and (3) how powerful the leadership position is (figurehead, does not make legislative decisions, or autocrat). I work backwards down the decision tree. I first start with a voting model 
and then show how candidates for leadership are groomed and selected in light of the voting. ${ }^{1}$ I make the following assumptions.

Voter i's expected utility when candidate $\mathrm{C}$ is chosen as leader equals

(1A) $U^{i}(C)=-B\left(\hat{x}_{i}-\left[w x_{c}+(1-w) \hat{x}_{m}\right]\right)^{2}-\left(\hat{a}-a_{c}\right)^{2}+K_{c}$ if $\mathrm{C}$ has been a leader before, and

$$
\begin{aligned}
U^{i}(C)= & -Q B\left(\hat{x}_{i}-\left[w x_{c}+(1-w) \hat{x}_{m}\right]\right)^{2}-.5[1-Q] B\left(\hat{x}_{i}-\left[w x_{c}+(1-w) \hat{x}_{m}\right]+\varepsilon\right)^{2} \\
& -.5[1-Q] B\left(\hat{x}_{i}-\left[w x_{c}+(1-w) \hat{x}_{m}\right]-\varepsilon\right)^{2}-\left(\hat{a}-a_{c}\right)^{2}+K_{c} \\
& =-B\left(\hat{x}_{i}-\left[w x_{c}+(1-w) \hat{x}_{m}\right]\right)^{2}-B[1-Q] \varepsilon^{2}-\left(\hat{a}-a_{c}\right)^{2}+K_{c}
\end{aligned}
$$

if $\mathrm{C}$ has not been chosen before.

Starting with the first line. $\hat{x}_{i}$ is voter i's most preferred policy position. Differences in policy position may reflect differences over the appropriate church doctrine and what is best for the religion's survival or it may represent more mundane concerns (see Wilde et al., 2010). $x_{c}$ is candidate C's most preferred position (known to all). $w$ is a weighting factor. If $w=1$, then $x_{c}$ will be implemented if $\mathrm{C}$ is chosen again as leader. ${ }^{2}$ If $w=0$, then

\footnotetext{
${ }^{1}$ In some religions, the congregation chooses the leader; in other religions, a select group of religious leaders choose the leader; and in a third variant, the leader chooses the next leader. Each of these can be characterized as voting, but obviously the last type is a degenerate case as there is only one voter. In still other religions, the leader is the owner of the church and the congregation chooses with which church to affiliate. In this case, the voting is with one's feet.

${ }^{2}$ One could use the notation $\hat{x}_{c}$ to denote C's most preferred position, but I have chosen to go without the hat to more readily distinguish between the role of the voter and the role of the candidate, although they may be the same person.
} 
$\hat{x}_{m}$, the median voter's most preferred position, will be implemented. The further the implemented position is from the voter's preferred position, the less utility that the voter will have. $B$ denotes the importance to the voters of the leader's policy relative to other characteristics of the candidate.

The next variables are the leader's valence characteristics--dimensions that are perpendicular to the issue space and valued the same by all participants. In contrast to policy, where voters disagree about which policy is best, there is general agreement among the voters concerning valence (regardless of the voter's preferred position). ${ }^{3}$

$\hat{a}$ is the optimal age of a leader and $a_{c}$ is candidate C's age. The age of a leader has both intrinsic and strategic value. With regard to intrinsic value, the optimal age $\hat{a}$, is the optimal balance between declining energy and increasing wisdom as a person gets older. When a leader's age is above the optimal, the leader's increased wisdom is not sufficient to overcome the loss of energy; when the leader's age is below the optimal, the leader's energy is not sufficient to overcome the lack of experience. It is possible that on occasion a potential leader is both young and experienced or old and energetic, but we are dealing here with averages not particular cases. The model does not critically depend on age having an intrinsic value. Therefore, if the reader is bothered by the assumption, the term $\left(\hat{a}-a_{c}\right)^{2}$ can be removed from the utility function.

$K_{c}>0$ is C's charisma - how well the members of the religion relate to the particular person. A larger value means that more people will be attracted to and stay with the religion.

I now concentrate on the voter's expected utility when the candidate has not been elected to office before. Not surprisingly, there is uncertainty about the candidate's policy preference. This uncertainty is captured by the stochastic term $(\varepsilon)$. Each voter has an

${ }^{3}$ Valence is a concept promoted by Enelow and Hinich (1982) and Stokes (1992) and now commonly employed in voting models (see for example, Ansolobehere and Snyder, 2000, Groseclose, 2001, and Hummel, 2010). 
unbiased estimate of a candidate's policy preference. The larger $Q$ is, the more certain the voters are about the candidate. ${ }^{4}$ If an individual has been the leader previously, the die has been tossed, the person's type has been revealed (as long as $w>0$ ), and the uncertainty no longer exists. ${ }^{5}$ When the appointment is for a term at a time, $w$ will be relatively small, possibly zero. The leader needs to worry about re-election, and so his policies while in office will bend more toward the median voter. When the appointment is for life, $w$ is much closer to 1 as the re-election constraint is no longer operative. The longer the leader has been in office, the more powerful the leader is (that is, the larger his scope of control), and the larger $w$ will be. So $w$ is itself a positive concave function of $t$ (length of time as leader) and $L$ (where $L=1$ when the appointment is for life; $L=0$, otherwise). For convenience, I assume that no two candidates are identical on all dimensions.

Proposition 1: Under the above conditions, there is a median voter.

It is most convenient to demonstrate this proposition by making use of Figures $1 \mathrm{~A}$ and 1B where $B=1, Q=1, w=1$, and $K_{c}$ is the same for all candidates. A more general proof is found in Appendix A. There are three voters whose preferences are on a left-right continuum: L (a voter weakly to the left of $\mathrm{M}$ ), $\mathrm{M}$ (the median voter), and $\mathrm{R}$ (a voter weakly to the right of M). ${ }^{6}$ The valence characteristic of the candidate (age) is measured vertically. The optimal age is on the horizontal line. Consequently, the center of each indifference circle is on this line, as well. If one concentrated on charisma (where more is better) rather than age, then only the lower hemisphere would be relevant.

\footnotetext{
4 Voters may have different degrees of uncertainty about different candidates. This may affect which candidate will be chosen, but does not affect the propositions.

${ }^{5}$ One could assume that incumbent uncertainty is reduced rather than being completely eliminated, but this would only make the presentation more complicated.

${ }^{6}$ Because age is a valence characteristics, the voter's preferences regarding age are not dependent on the voter's own age.
} 
FIGURE 1A: $\mathrm{x}^{*}$ is to the right of $\mathrm{M}$ and to the left of $\mathrm{R}$

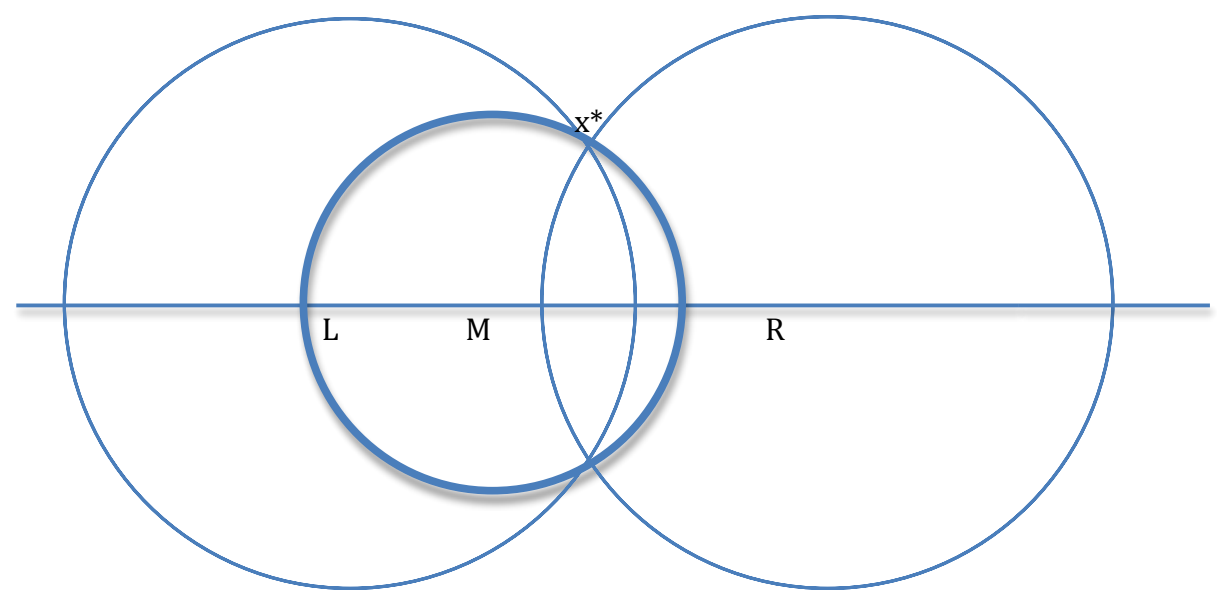

L's ideological position is to the left of M's ideological position. The valence characteristic is measured vertically. The optimal valence value is on the horizontal axis.

Any point preferred by $\mathrm{L}$ and $\mathrm{R}$ to $\mathrm{x}^{*}$ must also be preferred by $\mathrm{M}$ to $\mathrm{x}^{*}$. If $\mathrm{x}^{*}$ is the closest candidate to $\mathrm{M}$, then there is no other candidate preferred by a majority of voters.

FIGURE 1B: $\mathrm{x}^{*}$ is to the right of $\mathrm{L}, \mathrm{M}$ and $\mathrm{R}$

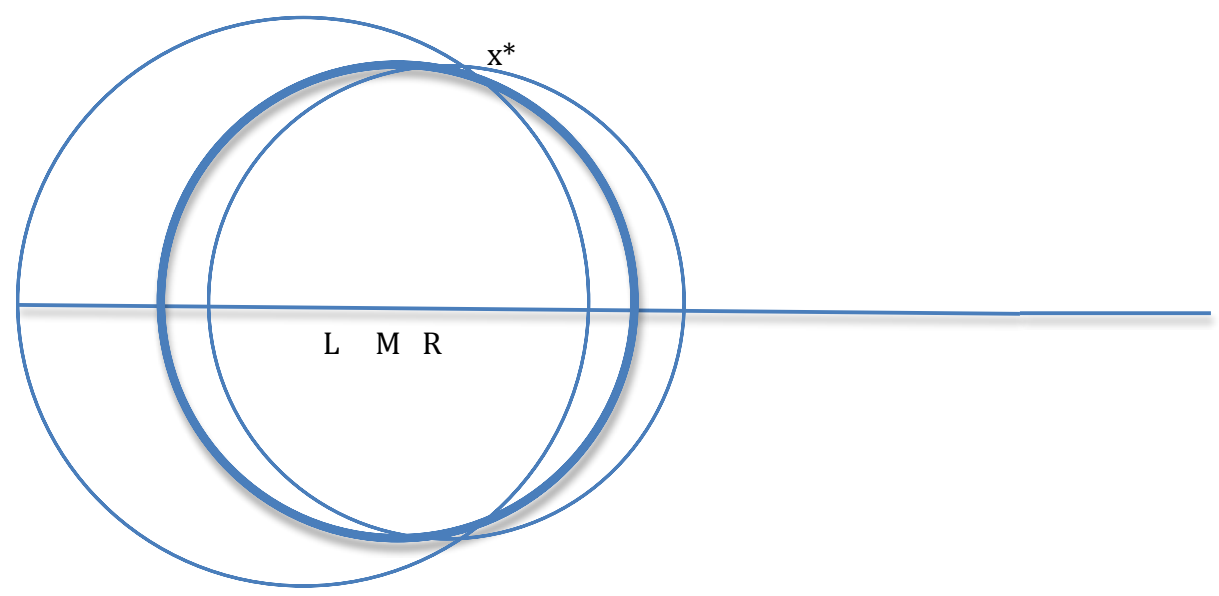

Any point preferred by $\mathrm{L}$ and $\mathrm{R}$ to $\mathrm{x}^{*}$ must also be preferred by $\mathrm{M}$ to $\mathrm{x}^{*}$. If $\mathrm{x} *$ is the closest candidate to $\mathrm{M}$, then there is no other candidate preferred by a majority of voters. 
The candidate strictly closest to $M$ is labeled $x^{*}$. All three voters' indifference curves are drawn through this point. For visual clarity, M's indifference curve is drawn with a heavier line. In Figure 1A, $\mathrm{x}^{*}$ 's policy position is between the preferred positions of $\mathrm{M}$ and $\mathrm{R}$; in Figure $1 \mathrm{~B}, \mathrm{x}^{*}$ 's policy position is to the right of the preferred positions of $\mathrm{L}, \mathrm{M}$ and $\mathrm{R}$. It is readily apparent that the only set of points preferred by both $\mathrm{L}$ and $\mathrm{R}$ to $\mathrm{x}^{*}$ are also preferred by $\mathrm{M}$ to $\mathrm{x}^{*}$. But we have assumed that $\mathrm{x}^{*}$ is the closest candidate to $\mathrm{M}^{\prime} \mathrm{s}$ most preferred position. So $x^{*}$ is the candidate that is preferred by a majority of voters to all other candidates. ${ }^{7}$ See Appendix $C$ for other solution concepts.

There are two natural extensions to the basic framework: (1) allowing for a more complex relationship between age and utility; and (2) allowing different cohorts to have different optimal age preferences. The first is easily taken care of. Let $f(a)$ be a positive monotonic transformation of $a$. Then one can just substitute $\left[f(\hat{a})-f\left(a_{c}\right)\right]^{2}$ for $\left(\hat{a}-a_{c}\right)^{2}$. The vertical axis is now measured in differences between $f(a)$ and $f(\hat{a})$ instead of differences between $a$ and $\hat{a}$. Proposition 1 still holds under these more general conditions.

The second extension requires a bit more work. Assume $k$ cohorts of $n$ voters, where each cohort lives for $k$ generations (equivalently, $k$ terms of office). Both $n$ and $k$ are odd. Hence, at the end of every generation, one cohort dies and a new one replaces it. Assume further that the median voter in each cohort has the same preference; otherwise, the distribution of policy preferences may differ from one cohort to another. Finally, allow different cohorts to have different age preferences that are monotonically increasing or decreasing according to the age of the cohort, although within cohort preferences are the same regarding age preference.

Proposition 2. The median voter in the $(k+1) / 2$ cohort will be the median voter overall. For the proof, see Appendix B.

\footnotetext{
${ }^{7}$ It is possible that $\mathrm{M}$ is indifferent between candidates $\mathrm{x}^{*}$ and $\mathrm{y}^{*}$, in which case, either by itself would be strictly preferred to any other candidate besides $x^{*}$ and $y^{*}$.
} 
I now turn to the comparative static results. Assume initially that the leader is not just a figurehead (that is, $B$ is large).

Proposition 3: When voting bodies elect leaders, leaders elected for life will be older when elected than leaders elected for a term are when they are first elected.

There are several strategic reasons for this. Candidates elected for life compromise less on their policy preferences than candidates elected for a term who would like to be reelected and therefore compromise more on their preferences. That is, candidates elected for life have larger $w$ values and therefore their policies are likely to be farther away from the median voter. This increases the potential for conflict between the leader and the voting body. At the margins, there is a tug of war between the electing body and the leader over control. The longer the leader is in power, the more power the leader amasses and the less influence the electing body has on the margin. An important method for the electing body to curb the leader's power is to elect the person when he is old and therefore less dynamic and with less time to accumulate power that distorts policy from the median. Other methods of controlling the elected-for-life leader such as writing preelection contracts will be covered when I discuss particular religions.

On the other side of the equation, when candidates are elected for one term at a time, an option value arises. This option value is greater for younger candidates. The logic is as follows: Once, elected the uncertainty about the candidate's preferences is resolved. If the median voter is pleased with the outcome, then the leader is likely to be re-elected. This option is more valuable when the leaders are younger and more likely to live long enough to serve several terms of office. Therefore, other things being more or less equal, younger candidates will be preferred over older candidates when neither candidate has been elected to office before. This option value is missing for leaders elected for life. It is true that being re-elected increases the power of the leader, but, in order to be re-elected, the leader's preferences must be reasonably aligned with the electorate. Therefore, the leader would have used his power to pursue actions that are in line with the median voter's preferences. 
Of course, other things need not be equal -- a younger candidate for life leadership may have preferences closer to the preferences of the electorate than an older candidate. But over many elections, we would expect those who are elected for life to be older than those who are not.

Candidates for leadership do not just appear. They typically have revealed some of their views beforehand. When mistakes are irreversible, as is the case when a leader is elected for life, there is a need for a better and more time-consuming screening process that reduces the uncertainty $(\varepsilon)$ about each candidate's preference to a reasonable level and eliminates people whose preferences are far from the median. More screening means that the electorate will have more information about the candidate's preferences than otherwise, but this takes more time. As a consequence, candidates will be older in religions that elect for life. This reinforces the results of Proposition 3.

Proposition 4: A leader-for-life will tend to choose a younger successor than the leaderfor-life chosen by the electorate. ${ }^{8}$

By choosing a younger person as the next leader, the present leader can have an influence on the church long after his own body has decayed. The alternative is for the leader to choose an older person as a successor, who will choose an older person as a successor, etc. But this method tends to be more risky than choosing a younger leader in the first place as each successor is only an imperfect agent of the previous leader. When a leaderfor-life chooses a successor, there is a random walk of preferences that is exacerbated by choosing older leaders who live fewer terms, thereby creating more random walks and more risk. To illustrate, suppose that in each period $t$, a leader chooses a person who is old and will only lead in the next period, $t+1$. To see the problem in its easiest form,

\footnotetext{
8 When the leader chooses the next leader, the policy outcome is a weighted average of the present leader's most preferred position and the previous leader's most preferred position, $w \hat{x}_{L}+(1-w) \hat{x}_{L-1}$. For ease of exposition, the explanation in the text assumes that $w=1$, but the results still hold when $w<1$, but increases as $t$ increases at a decreasing rate, which we have assumed.
} 
suppose further that that the leader in time $t$ with most preferred position $\hat{x}_{t}$ can choose a new leader in time $t+1$ with expected preference $E\left(\hat{x}_{t+1}\right)=\hat{x}_{t}$. Then a leader with most preferred position $\hat{x}_{t}$ will have a $Q$ chance of choosing a leader with a most preferred position $\hat{x}_{t+1}=\hat{x}_{t}$, a $.5[1-Q]$ chance of choosing a leader with a most preferred position, $\hat{x}_{t+1}=\hat{x}_{t}+\varepsilon$, and a $.5[1-Q]$ chance of choosing a leader with a most preferred position, $\hat{x}_{t+1}=\hat{x}_{t}-\varepsilon$. Under this scenario, the present leader knows that there will be a random walk of policy with $k-1$ steps over $k-1$ generations. Because utility is a concave function of the difference between the present leader's preferred position and the future leader's preferred position, the present leader is risk averse. With regard to policy, a less risky strategy for the existing leader would be to choose a new leader who is only 1 generation old. Then the random walk takes place only once over the $k-1$ generations--when the young leader is appointed and lives for the whole time. In contrast, when there is an election, the assembly is still around after the old leader dies and the problem of the random walk overtime disappears as the walk restarts from the most preferred candidate of the median voter in the assembly, which changes more slowly if at all. Appointing a younger leader means that the leader will garner more power over time. This is desirable from the old leader's perspective, but, as argued earlier, when the assembly appoints a leader, the assembly desires that a leader that is weaker vis-à-vis the assembly, and this means appointing an older leader. There will be greater uncertainty about a younger person's preferences regardless of who is appointing the new leader, but as just argued there are benefits accruing to the leader that do not accrue to the assembly when appointing a younger leader.

It is reasonable to believe that the correlation of a leader's preferences with his/her adult child's preferences is likely to be positive, even if not perfectly so. This means that in comparison to appointing an unrelated successor, there is less risk in appointing for life the leader's adult offspring while they are still relatively young. Coupled with other added benefits of hereditary succession, it is not surprising that offspring are often chosen as successors, even if there is no rule requiring it to be so. When one's offspring step into the leadership role, grooming for the leadership role can start at a very early age. At the same time, screening is limited to the leader's children, which allows for a relatively 
rapid elimination of the weaker candidates for leader. This reinforces the results of Proposition 4. Particularly when life expectancy was short, such hereditary succession resulted in the appointment of very young leaders.

When leaders cannot be removed from office, the leadership position can sometimes be stripped of power. For example, the gradual devolution of power of the English monarchy and, more germane to the topic of this paper, the Protestant Reformation's denial of the pope's power. In Protestant religions, power is considerably devolved so that the leader is much weaker. In the extreme case, the leader is only a figurehead and the voters' utility functions no longer depend on the leader's ideological position, $x_{c}$; that is $B=0$. Instead, the most important characteristics are the leader's age and charisma, $K_{c}$. The leader is the human embodiment of the abstract religious principles. This human connection between the leader and the followers becomes stronger the longer the leader has been in this role. We thus have the following proposition.

Proposition 5: When the assembly appoints a leader for life, leaders without power (that is, where $B=0$ ) will be elected at a younger age than those who are powerful (where $B$ is much larger).

Because the power of the leader is weaker and can be controlled, the risks of electing a younger person are greatly reduced. On the other side of the equation, the longer the leader has been the embodiment of the church, the stronger the connection the followers feel. Hence, symbolic leaders will tend to be appointed at a younger age.

All of the above deal with succession in existing religions. But founders of new religions do not have to bend to the existing power structure because there is none. In particular, they do not have to travel up the steps of the pyramid. Instead, they have to compete with other religions in gaining members. Hence, it should no be surprising that founders will tend to be younger when first recognized as the leader of the new religion than subsequent leaders in the established religion. 
TABLE 1A: REIGN AND AGE AT APPOINTMENT

\begin{tabular}{|c|c|c|c|c|c|c|c|c|c|c|}
\hline \multirow{2}{*}{$\begin{array}{l}\text { CATHOLIC } \\
\text { Pope }\end{array}$} & \multirow[b]{2}{*}{ reign } & \multirow[b]{2}{*}{ age } & \multicolumn{2}{|l|}{ ANGLICAN } & \multicolumn{3}{|l|}{ EPISCOPAL } & \multicolumn{3}{|c|}{ LUTHERAN A SYNOD } \\
\hline & & & Archbishop reign & age & Presiding Bisho & reign & age & President & reign & age \\
\hline Pius VI & $1775-1799$ & 63 & F. Cornwall 1768-1783 & 55 & W. White & $1789-1789$ & 41 & & & \\
\hline Pius VII & $1800-1823$ & 57 & J. Moore 1783-1805 & 53 & S. Seabury & 1789-1792 & 60 & & & \\
\hline Leo XII & $1823-1829$ & 63 & C. Manners $1805-1828$ & 50 & S. Provoost & 1792-1795 & 50 & & & \\
\hline Pius VIII & $1829-1830$ & 67 & W. Howley 1828-1848 & 62 & W. White & $1795-1836$ & 39 & & & \\
\hline Gregory XVI & $1831-1846$ & 65 & J. Sumner $1848-1862$ & 68 & A. Griswold & $1836-1843$ & 70 & & & \\
\hline Pius IX & $1846-1878$ & 54 & C. Longley $1862-1868$ & 68 & P. Chase & $1843-1852$ & & C. Walther & $1847-1850$ & 36 \\
\hline Leo XII & $1878-1903$ & 67 & $1868-1882$ & 57 & T. Brownell & $1852-1865$ & 73 & F. Wyneken & $1850-1864$ & 40 \\
\hline Pius $X$ & $1903-1914$ & 68 & E. Benson 1883-1896 & 54 & J. Hopkins & $1865-1868$ & 73 & C. Walther & $1864-1878$ & 53 \\
\hline Benedict XV & 1914-1922 & 59 & F. Temple $1896-1903$ & 75 & B. Smith & $1868-1884$ & 84 & H. Schwan & 1878-1899 & 59 \\
\hline Pius $\mathrm{X} 1$ & 1922-1939 & 64 & R. Davidso 1903-1928 & 55 & A. Lee & 1884-1887 & 77 & F. Pieper & 1899-1911 & 47 \\
\hline Pius XII & 1939-1958 & 63 & 1928-1942 & 64 & J. Williams & $1887-1889$ & 70 & F. Pfotenhaue & $1911-1935$ & 52 \\
\hline John XXIII & 1958-1963 & 78 & W. Temple 1942-1944 & 61 & T. Clark & 1889-1903 & 87 & J. Behnken & 1935-1962 & 51 \\
\hline Paul VI & 1963-1978 & 65 & G. Fisher $1945-1961$ & 58 & D. Tuttle & 1903-1923 & 66 & O. Harms & 1962-1969 & 61 \\
\hline John Paul I & 1978-1978 & 65 & A. Ramsey 1961-1974 & 57 & A. Garrett & 1923-1924 & 91 & J.. Preus II & -1981 & 49 \\
\hline John Paul II & 1978-2005 & 58 & F. Coggan 1974-1980 & 65 & E.Talbot & 1924-1926 & 76 & R. Bohlmann & 1981-1992 & 49 \\
\hline Benedict XVI & 2005-2012 & 78 & R. Runcie 1980-1991 & 59 & J. Murray & 1926-1929 & 69 & A.. Barry & 1992-2001 & 61 \\
\hline & & & 1991-2002 & 56 & C.Anderson & 1929-1930 & 64 & R. Kuhn & 2001-2001 & 64 \\
\hline & & & R. Williams 2003-2012 & 53 & J. Perry & 1930-1937 & 59 & G. Kieschnick & r $2001-2010$ & 58 \\
\hline & & & & & H.Tucker & 1938-1946 & 64 & M .Harrison & $2010-$ & 48 \\
\hline & & & & & H. Sherrill & 1947-1958 & 57 & & & \\
\hline appoint year & birth year $=$ & age & & & A. Lichtenbers & 1958-1964 & 58 & & & \\
\hline & & & & & J. Hines & $1965-1974$ & 55 & & & \\
\hline & & & & & J. Allin & 1974-1985 & 53 & & & \\
\hline AVERAGE & & 64.6 & & 59.4 & E. Browning & 1986-1997 & 57 & & & 52.0 \\
\hline standard de & of $a v$ & 1.6 & & 1.53 & $\begin{array}{l}\text { F. Griswold } \\
\text { K. Shori }\end{array}$ & $\begin{array}{l}\text { 1998-2006 } \\
2006-\end{array}$ & $\begin{array}{l}61 \\
52\end{array}$ & & & 2.2 \\
\hline AVERAGE & Pre 1926 & 62.7 & & 59.7 & & & 70.3 & & & \\
\hline standard dev & of average & 1.5 & & 2.6 & & & 3.7 & & & \\
\hline AVERAGE & 1926- & 67.8 & & 59.1 & & & 59.0 & & & \\
\hline standard d & f avers & 3.4 & & 1.4 & & & 1.5 & & & \\
\hline
\end{tabular}


TABLE 1B: REIGN AND AGE AT APPOINTMENT

LDS

prophet
COMMUNITY OF CHRIST

reign age President
CHABAD LUBAVITCH

reign age Rebbe reign

age

\section{Shneur Zalman}

Joseph Smith J 1830-184، Brigham Young 1844-187. John Taylor

$$
1877-188
$$

Wilford Woodru 1887-189i

Lorenzo Snow 1898-190.

Joseph Smith 1901-191i

Hebert Grant 1918-194! 62 W. Grant McMurr 1996-200.

George Smith 1945-195 75 Stephen M. Veaz 2005 -

David McKay 1951-1971 78

Joseph Smith 1970-197: 94

Harold Lee 1972-197: 73

Spencer Kimba 1973-198! 78

Ezra Benson 1985-199، 86

Howard Hunter 1994-199! 87

Gordon Hinkley 1995-200; 85

Thomas Monso 2008-
Dovber Schneuri (son)

VACANT

1788-181: $\quad 43$

$1812-182 \quad 39$

1827-1831

25 M. Schneersohn (son-in-law) 1831-186! 42

28 Shmuel Schneersohn (son) 1866-188. 32

43 VACANT 1882-1892

70 Sholom Dovber (son) 1892-1921 32

58 Yosef Schneersohn (son) 1920-195। 40

49 VACANT 1950-1951

49 Menachem Schneerson (son-in 1951-199، 49

48 VACANT 1994-

not included in average

AVERAGE

standard dev average
72.7

4.4

3

(1)


TABLE 2: DIFFERENCES IN AGE AND T-VALUES

CHURCH
MEAN AGE

t-value

ANGLICAN difference

t-value

LUTHERAN differene

t-value

LDS difference

t-value

C OF CHRIST difference

t-value
CATHOLIC ANGLICAN LUTHERAN

64.6

52.3
5.2

3.3

12.3

7.7

7.1

4.7

$-8.9$

$-20.4$

$-8.9$

1.3

23.4

5.3

9.7

2.0 


\section{The Structure of Churches and the Age of their Leaders when First Appointed}

The theory developed in the previous section will now be used to provide insight into particular religions. The starting line for the data is the closest appointment to 1776 as that was about the time that the Episcopal Church of the United States split from the Church of England and since that time a number of American churches have been created. ${ }^{9}$ The relevant data is found in Tables $1 \mathrm{~A}, 1 \mathrm{~B}$ and 2 . Tables $1 \mathrm{~A}$ and $1 \mathrm{~B}$ provide the data used in our discussion of the individual cases. Table 2 shows that the pair-wise comparisons have statistically significant differences in age of (first) appointment to the leadership.

\section{A. Roman Catholic Church: The Pope and the Cardinals}

The Roman Catholic Church is centralized and hierarchical. The College of Cardinals elects the pope, who serves until he dies. ${ }^{10}$ This is an elected autocracy. The pope has considerable power over church policy. The College of Cardinals is not a legislative body and has no de jure ruling power, except when there is a papal vacancy (and even then, its powers are extremely circumscribed). In turn, the pope elects new cardinals to the college.

I have argued that, other things being equal, electing a leader for life results in the electoral body electing older religious leaders than would be the case if the leader were elected for a term. This effect is magnified when the leader is an autocrat as there are then fewer ways to limit the damage from the leader. In turn, this requires a longer period of screening for the right types. In the Catholic Church, screening is done through discrete steps (priest, bishop, and cardinal) that

\footnotetext{
${ }^{9}$ Since I am comparing religions over roughly the same time period, I do not have to control for increases in life expectancy over time. Actually the correct variable would not be life expectancy, but expected life given that the person had already reached $20+$ years of age.

10 The Code of Canon Law has no provision that allows a pope's removal from office. A pope may resign, but his resignation must be "made freely." The last pope to resign was Gregory XII, who did so in 1415 to end the battle for the papacy known as the Western Schism.
} 
make for election at an older age. For now, just keep in mind that since 1775, the average age of a pope when elected is 65 and the average length of time being pope has been 15 years. ${ }^{11}$

The College of Cardinals might try other ways to limit the influence of the pope than electing older leaders. One method is to have the prospective pope promise to carry out certain policies. In 1352 the College of Cardinals had prospective popes sign a formal "capitulation." But the commitment was not credible. After being elected, Pope Innocent VI declared the capitulation to be invalid. ${ }^{12}$ And much of the history thereafter followed a similar pattern of broken promises until the practice of writing capitulations died out in the 16th century. ${ }^{13}$

The College of Cardinals elects the pope, but the pope elects new members to the College of Cardinals, thereby influencing the election of the next pope. It would seem that successive popes might expand their influence and their dead hand on the future by increasing the size of the college and filling it with like-minded young cardinals. But from 1587, when Sixtus V fixed the number of cardinals at 70 (in Postquam verus) until 1970, when Pope Paul VI increased the size of the electorate to 120 , there were no increases in the size of the electorate. ${ }^{14}$ Why did Sixtus limit the size to 70 ? If he were merely interested in adjusting the number of cardinals to be optimal for administering the size of the Church, then he would not need to fix the size in a Papal Bull; he could have announced a ratio of cardinals to bishops instead. It seems plausible that he wanted to prevent an upward creep in the size of the electorate that would arise if each pope tried to increase his influence. But why did future Popes accept the limit rather than increasing it by

\footnotetext{
${ }^{11}$ Note that the four longest reigning popes have been during this time period.

12 "Episcopal and Pontifical Capitulations." Catholic Encyclopedia (1913).

${ }^{13}$ According to Baumgartner (2003, p. 192), "secretaries of state rarely have been elected [to pope] because they are too closely identified with the dead pope." This is another, albeit quite modest, method of reducing the power of the pope.

${ }^{14}$ Note that the Councils of Constance (1414-18) and Basel (1431-1437) had limited the number of cardinals to 24. See U.S. Conference of Bishops College of Cardinals Backgrounder www.usccb.org/pope/CollegeofCardinalsBackgrounder.pdf
} 
FIGURE 2: AGE OF APPOINTMENT TO CARDINAL BEFORE AND AFTER PAUL VI REFORM

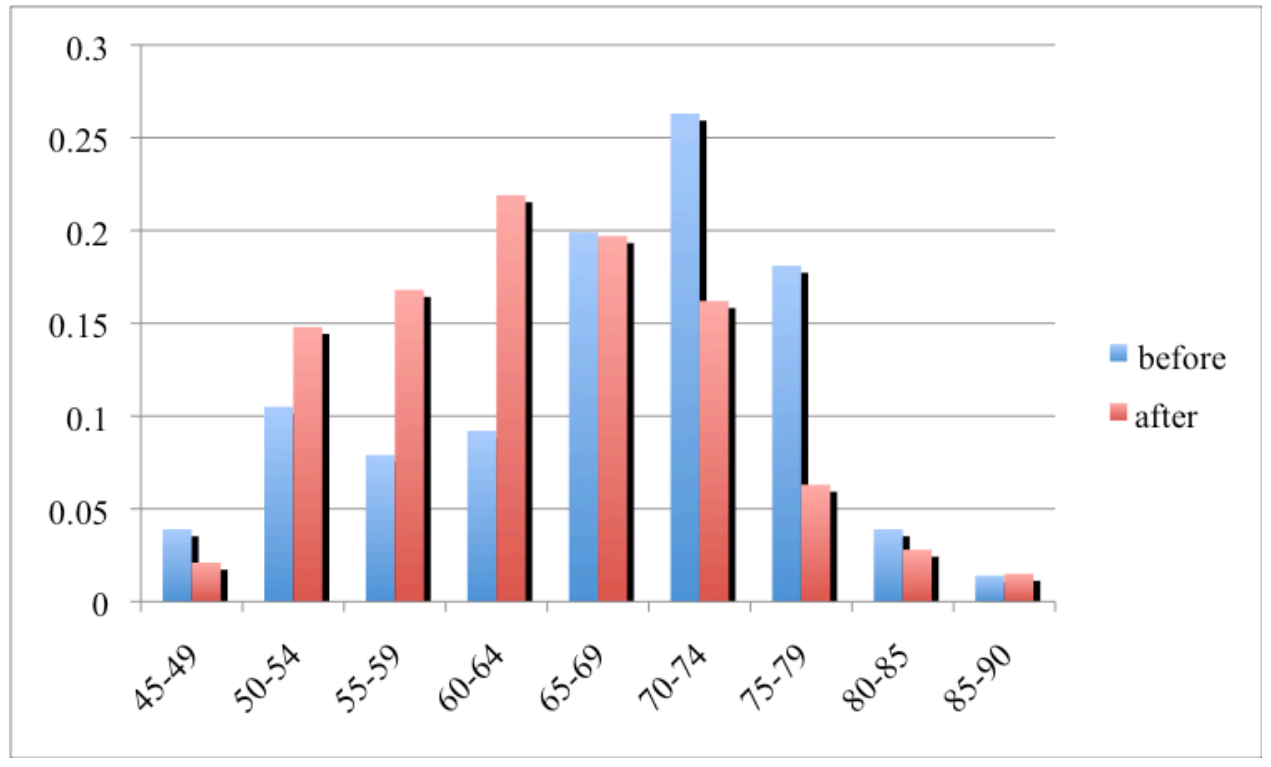


issuing their own Papal Bull? If the next pope increased the number of cardinals, then the pope after that would likely increase the number as well. So 70 became a focal point and had a life of its own. Finally in the years 1967 to 1970, Pope Paul VI limited the electorate to cardinals under 80 years of age and increased the size of the electorate to 120 (so that the total number of cardinals could be much higher). This enabled Paul VI to expand the influence of the church in both the East (by making Patriarchs of the Eastern Catholic Church into cardinals) and the South (by expanding the influence of the church in Africa and South America) ${ }^{15}$ And more to the point of this paper, it enabled him to drastically change the makeup of the electors. Note that most of the cardinals still kept their positions after 80 (the main exception being the Roman curia) as well as the pope himself; so it was not so much about energizing the day-to-day operations of the church as influencing future elections. ${ }^{16}$ Of those elevated to cardinal in the 13 years before Paul VI was elected Pope, $18.1 \%$ were in the $75-79$ age-group; while, in the 13 years after Paul VI made his announcement, only $6.3 \%$ were in this age-group (the whole shift in the distribution can be seen in Figure 2). Because bishops are made cardinals only at the occasion of consistories that are held at irregular times, appointing cardinals in the 75-79 age group could mean that they would be too old to vote in the near future and that the present pope might not have had the chance to replace them (unless the pope chose to go over the 120 limit). More important, appointing too many cardinals in the 75-79 age-group would mean even greater expansion of the College of Cardinals when they reached 80.

Although I have focused this paper on the time period starting with the founding of the Episcopal Church in the United States, it is insightful to compare the age and length of reign of popes before and after Pius V (in 1775). I start with Innocent VII in 1404 because that is the first time that the birth date of the pope is available. In the first period, the average age of election to pope

\footnotetext{
${ }^{15}$ See Backgrounder. In general, creating new Cardinals has been a way of gaining money for the church and diluting the power of the existing set of cardinals. See Pham (2004).

${ }^{16}$ Cardinal Ratzinger's challenger for pope, Jorge Bergoglio, was 69. John Paul II, the youngest cardinal to be elected to pope in the 20th century, was elected in 1978 after two Popes had already died that year. Among other reasons for electing John Paul II, the College of Cardinals may have been concerned about another pope dying in quick succession.
} 
was 62 , while the average reign was 7.5 years; in the second period, the average age of election was 65 , while the average length of reign doubled to 15 years. Now that life expectancy is longer and hence expected length of reign for any given age of election is longer, it is not surprising that the average age at election is older.

\section{B. The Anglican Church}

The Anglican Church is an obvious religious institution for comparison to the Roman Catholic Church. Until Henry VIII, the Catholic Church in England was under the authority of Rome, and the Church of England still considers itself to be a Catholic Church. ${ }^{17}$ And until 1975, the Archbishop of Canterbury was appointed for life. ${ }^{18}$ But there are significant differences, all of which make the Archbishop far less influential. The British monarch has the constitutional title of Supreme Governor of the Church of England, and the canon law of the Church of England acknowledges that the monarch "is the highest power under God in this kingdom, and has supreme authority over all persons in all causes, as well ecclesiastical as civil." Over time, the influence of the monarch (and later parliament and the prime minister) on the Church greatly waned, so that now power is in the hands of the General Synod, whose membership includes bishops, elected clergy and elected laity (there are no cardinals). The Archbishop can use his rhetorical skills, but he has virtually no legal power and therefore there is at best only a modest need to constrain his power by appointing him at an older age. Indeed, because human connections deepen with time, it makes sense to appoint the living embodiment of the church at a younger age (Proposition 5). ${ }^{19}$

\footnotetext{
${ }^{17}$ In fact, Anglican priests can become Catholic priests even if they are married.

18 Since 1975, there has been a mandatory retirement age at 70 . This has coincided with a slight shift downward of the age of appointment (as predicted). However this time period only includes three appointments, rendering the results statistically insignificant.

19 Since 1925, when pensions were instituted, all archbishops except William Temple, who died prematurely, retired.
} 


\section{The Episcopal Church}

The Episcopal Church was organized shortly after the American Revolution, when it was forced to break with the Church of England because the Church of England clergy were required to swear allegiance to the British monarch, which, of course, was treasonable. It thus makes sense to compare the Episcopal Church and the Church of England because they are so close in theology, but differ in structure.

In the Episcopal Church, bishops are ordained by three or more existing bishops. Before 1926, the first person to be ordained bishop became the Presiding Bishop of the Episcopal Church. Not surprisingly, this meant that the average age at taking office was 70 (see Table 1A). Then the rules changed. The Presiding Bishop became an elected position and it was no longer for life. Since 1926, the average age of being elected Presiding Bishop has been 59. In contrast, for the Church of England, the average age of appointment to Archbishop went down only a half a year, while for the Catholic Church, the average age of election to Pope, went up 5 years between these two time periods. So this is additional evidence in line with the arguments made earlier.

\section{The Lutheran Church--Missouri Synod}

The Lutheran Church --Missouri Synod was founded in 1847. It is the second largest Lutheran body in the US after the Evangelical Lutheran Church of America, which formed in 1988 from the merger of three Lutheran churches (and thus is too young to make statistical comparisons).

The Lutheran Church Missouri Synod is led by a Synodical President, who is chosen at a Synodical convention (composed of professional clergymen and lay representatives from the member congregations). The convention is held every three years and so the term of the presidency is also three years. The Synod, let alone its head, has virtually no influence on individual churches within the Synod. The Synod's Constitution, Article VII states the following: "In its relation to its members, the Synod is not an ecclesiastical government exercising legislative or coercive powers, and with respect to the individual congregation's right of selfgovernment it is but an advisory body. Accordingly, no resolution of the Synod imposing anything upon the individual congregation is of binding force if it is not in accordance with the Word of God or if it appears to be inexpedient as far as the condition of the congregation is concerned. ... Membership of a congregation in the Synod gives the Synod no equity in the 
property of the congregation." Because there is no need to limit the power of the President still further, it should not be surprising that the average age of the president when first elected is 52 .

\section{E. Church Of Christ of the Latter-day Saints}

The Mormon Church was founded by Joseph Smith in 1830. After Joseph Smith died in 1844, there was a succession crisis and the Mormon Church split into several Mormon branches. ${ }^{20}$ In this section, I consider the Mormon Church that is based in Salt Lake City and known as the Church of Christ of the Latter-day Saints (LDS). The Latter-day Saints consider Brigham Young to be the leader following Smith.

The Church is hierarchical and headed by a President (the Prophet), the Quorum of the Twelve Apostles, and the First Presidency (which includes the President and two counselors, often chosen from The Quorum of the Twelve Apostles). ${ }^{21}$ Except for Joseph Smith, who was ordained when he was 24 , the average age of ordination to President is at a very old age (73). ${ }^{22}$ On the other hand, appointment to the Quorum of the Twelve Apostles has been at a very young age (49). ${ }^{23}$ The theoretical construct derived earlier explains these, as well as other unusual aspects regarding age.

Because Joseph Smith was the founder of Mormonism, we should not be surprised that he was young and that most of his followers would be young. And for similar reasons, the second generation is likely to be young, especially so, when the leader dies at a young age, as Smith did

\footnotetext{
${ }^{20}$ In new religions, it is extremely common for power struggles to result in the splitting of the religion into two or more sects.
}

${ }^{21}$ Below in the hierarchy is the Presidency of the Seventy, the First and Second Quorum of the Seventy, etc.

${ }^{22}$ Early presidents were Presidents of the Quorum of the Twelve Apostles.

${ }^{23}$ This does not include the first Apostles, appointed before Brigham Young became president, who were on average 31 years old when appointed. 
at age 38. So, Brigham Young, his successor, is the second youngest to assume the role of President in the LDS church at age 46.

But why did all the others assume the role of President at such an old age (the youngest being 60 and the average since Brigham Young being 76)? As was the case in the early years of the Episcopal Church, the Presidency is in order of appointment. But for the LDS Church, the critical appointment is to the Quorum of the Twelve Apostles. ${ }^{24}$ In order to be president, everyone appointed before you has to die. So even if you were appointed at a very young age, you could be a very old man by the time you become president if others before you were also young (which has been the typical case, particularly in the earlier years). There are also positive reasons for a long wait - the members of quorum are being groomed for the job during this time.

Now throughout this paper, I have treated most of the institutions as fixed, but some institutions are more fixed than others. As already mentioned, the Episcopal Church changed the appointment to the presidency from order of ordination as bishop to an election. In that case, the power was in the hands of the bishops, not the presidency, and most of the bishops preferred to have the president of their own choosing, rather than a mechanical ordering, where only a very small percentage would gain the presidency. In contrast, the LDS Church is hierarchical and the President, as well as a majority of the Quorum of Twelve, have little to gain from having an election. So, unless power becomes more diffuse, elections to the presidency itself seem very unlikely.

When a vacancy arises, appointment to the Quorum of Twelve is by unanimous decision of the First Presidency and the Quorum of Twelve Apostles. One suspects that the President is far more influential than the unanimity requirement suggests. One would in general expect that the age of the new appointee to be on average less than the existing appointees both because the appointments take place later in time and because younger appointees are more likely to survive

24 Unlike the Catholic Church, there is not a professional clergy. At the local level, the church leaders are drawn from the laity, who work on a part-time volunteer-basis without a stipend. When people are appointed to the Quorum of Twelve Apostles, they are now asked to retire from their professional careers. 
long enough to be president. This is an implication of Proposition 4. The president chooses the next president subject to a death lottery. All of this is most evident when adding heredity to the mix (Proposition 5 again). Five Quorum of Twelve members were appointed by their fathers when president. These were Brigham Young (appointed at 31 by Brigham Young), John W. Taylor (appointed at 26 by John Taylor), Abraham Woodruff (appointed at 25 by Wilford Woodruff), Hyrum M. Smith (appointed at 29 by Joseph F. Smith), and Joseph Fielding Smith (appointed at 34 by Joseph F. Smith). ${ }^{25}$ The age of appointment was significantly younger for these five than the average age of appointment to the Quorum of Twelve (which, includes these 5 and, as already noted, is 49). ${ }^{26}$ However, the death lottery was not kind to some of them -Abraham Woodruff died at 31 and Hyrum Smith died at 45.

At this juncture, it is useful to remember that the statement is "other things being equal, a leader prefers to choose a younger rather than an older person as the new leader." In the days of polygamy, Mormon leaders had many sons that were often of roughly similar age. In such cases, the leaders chose that son who was most promising as a future leader to be a member of the Quorum of Twelve. And outside the nepotism circle, there has been a process of selecting and grooming people for future leadership positions

\section{F. Community of Christ}

The Community of Christ, formerly known as the Reorganized Church of Jesus Christ of Latter Day Saints, is a Mormon church. Like the Church of Christ and the Latter-day Saints, its founder is Joseph Smith, Jr. The Community of Christ also shares many of the structural elements with the LDS church, including a presidency and a Quorum of the Twelve Apostles. Despite these similarities, there are certain dramatic differences between the two churches, some of which are

25 A similar practice occurred in the Roman Catholic Church. Popes ostensibly did not have children, but from the eleventh century until 1692, when the practice was outlawed, it was customary for the Pope to nominate at least one relative (typically a nephew but at times called a nephew, but actually the Pope's child) to the rank of cardinal. The word for nephew in Latin is nepos, nepotis, from which the word nepotism is derived.

${ }^{26}$ Certain restrictions (such as being a deacon) prevented the ages from going much younger. 
played out with regard to age. The average age at being appointed President of the Community of Christ is 44 in comparison to the average age of being appointed to the President of LDS, which is 73 .

In the Community of Christ, the president chooses his successor, and until 1996 all of the Presidents were descendants of Joseph Smith. In 1996, Wallace Smith retired (only the second prophet to do so), and not having any male heirs (and for some reason, not wanting to choose nephews), chose W. Grant McMurray, who was 39 at the time. Under a cloud, Grant McMurray retired 8 years later and appointed Stephen Veazey, 48. As has been argued earlier, when leaders choose their successors, the successors tend to be young. There is little advantage to choosing an older person since the successor and the successor's chosen successor are subject to a random walk. Because the president who does the appointing is now out of the picture, he will not be choosing his successor's successor, as is the case with the cardinals in the Roman Catholic Church.

\section{G. Chabad Lubavitch}

The Chabad Lubavitch movement is a branch of Hasidism founded by Rabbi Schneur Zalman around 250 years ago. In certain ways, the Community of Christ is more similar to Chabad Lubavitch than it is to LDS, and that is the reason why we now turn our attention to Chabad Lubavitch. Chabad Lubavitch had a "hereditary-like" structure in that all of the successor Rebbes have been sons or sons-in-law of the previous Rebbe. Especially, in earlier years when people died at an earlier age, this would mean that a son would take over at a very young age. Indeed, in one case, the son was only 23 when his father died; consequently the position was left open for 10 years, until he was older and more experienced. The average age of appointment is $40 .{ }^{27}$ Rebbe Menachem Schneerson had no children, and, when he died in 1994, there was no system for anointing a new Rebbe (partially, because many of his followers felt that he was the Messiah and that there would be no need for one). As a result, there has been no new Rebbe and the group has struggled to maintain its coherence.

${ }^{27}$ In Judaism, the congregation chooses the Rabbi and can replace the Rabbi. 


\section{H. Jehovah's Witnesses}

We have looked at the power struggle between the electing body and the elected-for-life leader that results in older leaders being elected under such circumstances. This power struggle is very evident in the short time period that the Jehovah's Witnesses have existed, where the relative power of the leader vis-à-vis the electing body has rapidly changed from one leader to the next. Unfortunately, the secretiveness of the Jehovah's Witnesses, the amorphous structure of power, and the short time period for each episode does not allow for a quantitative study. Nevertheless, the general outline is still insightful.

Charles Taze Russell co-founded Zion's Watch Tower Tract Society (now known as the Jehovah's Witnesses) in 1881, and in 1884 the corporation was officially registered in Pennsylvania, with Russell as president. Like many other religious founders, he was young when he started the religion, being only 29 in 1881. Joseph Franklin Rutherford was 47 when he was installed as the second president of the corporation. He envisioned the Watch Tower Society as a theocracy and undertook steps to centralize power, including the appointment of leaders for each congregation. A power struggle erupted between Rutherford and four of the seven Board of Directors, who accused him of autocratic behavior. ${ }^{28}$ But Rutherford gained a legal opinion that these four were not legally directors; he then replaced them with four new sympathetic directors. However, this was not the end of the litigation and eventually the four ousted directors obtained a court opinion that claimed Rutherford's actions were "wholly unlawful".

At the age of 35, Nathan Knorr was named the third president of the Watch Tower Bible and Tract Society. It appears that he never had the power of his predecessor, and, before his death, the power of the presidency was completely absorbed by The Governing Body. ${ }^{29}$

Today, the president is in charge of the day-to-day operations of the society (for example, the printing of tracts), but he has nothing to do with theological concerns and the structure of the

${ }^{28}$ As was the case for the Mormons, the power struggle resulted in the creation of new sects.

${ }^{29}$ The relationship between the Governing Body and the Board of Directors is murky. At one time there was considerable overlap in personnel. Later the Board of Directors faded away. The Governing Body itself was announced years after its ostensible beginning. 
Jehovah's Witnesses. Instead religious policy is determined by the 9-member Governing Body that requires a two-thirds majority for a proposal to pass.

Members of The Governing Body are appointed for life and when a member dies, the remaining members appoint his replacement. There are a number of crosscurrents, making a prediction about age more difficult in this case. Nevertheless, we can make limited predictions. We start by comparing the Jehovah's Witnesses to the Catholic Church. Both are hierarchical and, in both, appointment to the leadership position (the pope of the Catholic Church and the governing body of the Jehovah's Witnesses) is for life. Both of these lead to older age when appointed. However, in the case of the Jehovah's Witnesses, each member of the governing body has only 1/9 the power and there is no need to go through a hierarchy of priest, bishop and cardinal in order to be appointed to the governing body as there is little hierarchy below the governing body. Furthermore, as the existing members age, they are appointing people to carry on their policies after the existing members die. For all these reasons, one would expect the members of The Governing Body to be much younger on average when first appointed than the popes. And indeed, this appears to be case. For the set of members as of April 2007, the average age of appointment was $56 .^{30}$ On the other side, we would expect the age at appointment to The Governing Body would be older than the age of appointment to leader in a hereditary system. And this too, holds.

\section{The Dalai Lama and the Gelug School of Tibetan Buddhism}

At first blush, the Dalai Lama could be viewed as a prime counterexample to the arguments made in this paper as he is appointed at a very young age and holds his position for life. But, as will be seen, the facts accord with the theory. In practice the tenure was extremely short, and in the $18^{\text {th }}$ and $19^{\text {th }}$ century, tenure as leader was far shorter than any of the other religions we have looked at. ${ }^{31}$

30 This is the latest set from jehovahswitness-publications.com/governingbodymembers.aspx

31 For obvious reasons, the tenure of Russian Orthodox Patriarchs was also very short during the Soviet Period. 
As I have suggested throughout this paper, the issue is how to control the leader who is elected for life. The Tibetan Buddhists employ several methods that I have not considered up to now. Dalai Lamas are raised in monasteries and subjected to intense indoctrination as they grow up. But as most parents realize, their children do not always become the adults that their parents want. And so the Dalai Lama may grow up being more interested in wine, women and song than spiritual matters (as was the case for the 6th Dalai Lama), and even if the Dalai Lama is more serious, his politics may clash with others.

So how is the Dalai Lama constrained? First, there are Regents who are in charge while the Dalai Lama is a minor. Sometimes the Regent remains in charge even when the Dalai Lama is much older, and when the 5th Dalai Lama died, it was 17 years before his death was announced. But all of these methods are limited. So more serious measures may need to be undertaken. The 6th Dalai Lama was kidnapped and killed at the age of 23 in 1704 and a number of other Dalai Lamas were killed by poisoning in the following 200 years. ${ }^{32}$ From 1678 until 1895, Dalai Lamas ruled for a total of 8 years (see Table 3). So the real power was in the hands of other religious leaders (more or less the equivalent of cardinals) or foreign interlopers (the Chinese) or a combination of the two. Unfortunately, the palace intrigue is secret; so we cannot say how the powers behind the throne achieved their power. ${ }^{33}$

Until now, we have been looking at the struggle for power within a religion. However, these internal struggles pale in comparison to the struggle between Tibetan Buddhists and the Chinese government that has occurred since the Chinese invaded Tibet in 1950. This power struggle magnifies the behavioral relations that we have been discussing and at the same time creates greater pressure for institutional change within the religion.

32 See Norbu and Turnbull (1986, p. 311). Thubten Jigme Norbu is the elder brother of the present 14th Dalai Lama.

33 The choice of leaders in other religions is often behind smoke (literally for the Roman Catholic Church) and mirrors. But here even the mirrors are absent. 
TABLE 3: DALAI LAMAS AND REGENTS SINCE 1678

Regent Sangye Gyatso (1678 - 1703)

7. Dalai Lama Tsangyang Gyatso (1683 - 1706)

Regent Ngawang Rinchen (1703 - 1706

8. Dalai Lama Jamphel Gyatso (1758 - 1804)

Regent, the sixth Demo Rinpoche (1757 - 1777)

Regent, the first Tsemonling Rinpoche (1777 - 1786)

Dalai Lama ruled (1786-1791)

Regent, the eighth Kundeling Lama (1791 - 1806)

9. Dalai Lama Lungtok Gyatso (1806 - 1815)

Regent, the eighth Kundeling Lama (1806 - 1811)

Regent, the seventh Demo Rinpoche (1811 - 1816)

10. Dalai Lama Tsultrim Gyatso (1816 - 1837)

Regent, the seventh Demo Rinpoche (1816 - 1818)

Regent, the second Tsemonling Lama (1819 - 1838)

11. Dalai Lama Khendrup Gyatso (1838 - 1856)

Regent, the second Tsemonling Lama (1838 - 1844)

Regent, the third Reting Rinpoche (1845 - 1855)

\section{Dalai Lama ruled (1855-1856)}

Regent, the third Reting Rinpoche (1855 - 1856)

12. Dalai Lama Trinley Gyatso (1856 - 1875)

Regent, the third Reting Rinpoche (1856 - 1862)

Regent Dedruk Khyenrab Wangchuk (1864 - 1873)

Dalai Lama ruled (1873-1875)

Regent, the tenth Kundeling Lama Tatsak Ngawang Pelden (1875 - 1876)

11. Dalai Lama Thubten Gyatso (1876-1933)

Regent, the tenth Kundeling Lama Tatsak Ngawang Pelden (1875 - 1886)

Regent, the ninth Demo Rinpoche Lozang Trinlé (1886 - 1895)

\section{Dalai Lama ruled (1895-1933)}

Regent, the fifth Reting Rinpoche, Jamphel Yeshe Gyaltsen (1933 - 1935)

12. Dalai Lama Tenzin Gyatso (1935-present)

Regent, the fifth Reting Rinpoche, Jamphel Yeshe Gyaltsen (1935 - 1941)

Regent Taktra Rinpoche (1942 -1950)

Dalai Lama Tenzin Gyatso (1950-present) 
In order to move the discussion forward, we need to know some more details about Tibetan Buddhism. Tibetan Buddhism is not a centralized religion; rather it is a complex intertwining of religious orders or schools. Even within a school, each monastery uses its own set of commentaries and texts. In recent centuries, the Dalai Lama, as leader of the Gelug School, has been the temporal head of Tibet and the most important spiritual leader. But in earlier centuries, the Sakya and then the Kagyu schools ruled Tibet. Within the Gelug School, the two most important spiritual leaders are the Dalai Lama and the Panchen Lama. The Dalai Lama must recognize the reincarnation of the Panchen Lama and the Panchen Lama must recognize the reincarnation of the Dalai Lama, but otherwise neither is granted spiritual authority over the other. So historically there has been a lot of competition for power.

We now have the background necessary for understanding some of Tibet's recent history. In 1959, after the Chinese had squashed a rebellion by the Tibetans, the Dalai Lama fled Tibet to India. The Dalai Lama is now 74. Locked in a power struggle with the Chinese over control of Tibetan Buddhism, the Dalai Lama needs to alter the traditional arrangements. In particular, the Dalai Lama needs to avoid the power vacuum that could occur until the reincarnated Dalai Lama reaches maturity. The most important method is to appoint before his death, a regent that commands spiritual respect and is young enough to be a vibrant presence over the next decades. The likely regent is the 17th Karmapa, spiritual head of the Karma Kagyu School, who is now 23. ${ }^{34}$ Even though it is traditional to have someone from the Gelug School be a regent, it should not be surprising that internal differences pale in the face of the Chinese onslaught and that the Dalai Lama would want to install a young person for the reasons we have given earlier. ${ }^{35}$ The Dalai Lama has spoken about the possibility of ending reincarnation, but the problem is that many Tibetan Buddhists would continue believing that the Dalai Lama will be reincarnated and the Chinese will take advantage of this. The Dalai Lama has also talked about reincarnating before he dies. The Dalai Lama claimed that under a doctrine called madey tulku, he can select

\footnotetext{
${ }^{34}$ See http://www.newsweek.com/id/185796/page/2

35 Throughout this paper, we have focused on averages rather than particular observations (let alone speculative outcomes). So, this should be seen as evidence consistent with the theory, but not statistically meaningful.
} 
his own reincarnation while still alive. This would allow the Dalai Lama to shorten the period without a leader and control the education of his replacement. ${ }^{36}$

\section{Concluding Remarks}

This paper provides a convenient metric, age, that allows for comparisons both over time and across religions. ${ }^{37}$

In some religions the power of the church leader is limited by having policy in the hands of a synod and the leader is elected for a set term. In other religions, the power of the church leader is less constrained because there is no legislative body and the appointment is for life. In such cases, the main methods of control are to have longer periods of screening and to elect someone who will be in power for a relatively short period. Today, the main method of accomplishing this is to elect older leaders; at other times and places, murder was another option.

In contrast, the leader's main way of having an effect beyond the grave is to directly choose the next leader or, if he cannot choose the next leader, choose the electors who will choose the next leader. In the former case, this leads to younger rather than older leaders being chosen; in the latter case, this leads to the leader "stacking the deck" of electors by increasing the size of the electoral body and possible eliminating some of the electors chosen by previous leaders.

36 The Chinese State Administration for Religious Affairs has responded to this threat by issuing a 14-part set of regulations. Among the regulations are the following: The so-called reincarnated living Buddha without government approval is illegal and invalid; anyone outside China is banned from taking part in the process of seeking and recognizing a living Buddha. See http://en.wikipedia.org/wiki/State_Religious_Affairs_Bureau_Order_No._5 This regulation clearly excludes the Dalai Lama from taking part.

37 In Appendix D (not included), I provide a cross-section regression of different religions. While the results corroborate the arguments presented in this paper and are statistically significant, the sample size is too small to be convincing. 
I have shown how different institutional arrangements affect the choice of a leader. One might argue that a more fundamental question is why the particular institutional arrangement was chosen in the first place. But this "more fundamental" question cannot be fully answered until one knows the effects of various institutional arrangements. That is, without knowing the effect of particular institutional arrangements, one cannot explain why a particular institutional arrangement was chosen. Furthermore, it is conceivable that institutions do not matter. However, it has been shown that when it comes to the age of the leader when first chosen, institutions do matter.

While I have focused on religious institutions, the same analysis should hold for politics, more generally. An insightful comparison is between the Doges of Venice and the Doges of Genoa. ${ }^{38}$ The former were appointed for life, while the latter (after 1527) were appointed for two-year terms. Unfortunately, for Genoa, I have only been able to obtain birthdates for those who became doges after 1700. For Venice, a consistent series starts a century earlier. Napoleon ended the reign of both doges in 1797. Here are the relevant numbers: average age at appointment (for Genoa--60.4; for Venice since 1700--66.9; for Venice since 160069.7) and average reign for Venice (6.4 years since 1600 and 8.8 years since 1700 ). So here too age is a weapon for reigning in the power of the leader.

It would be interesting to extend the analysis so that succession in authoritarian and totalitarian governments is also explained. This will not be an easy task, however, as the power relationships may not at all resemble the stated legal relationships. Is the voting of the assembly a rubber stamp of what has already been decided by other means? Can the leader really be removed by the parliament? Is the real power in the hands of the presidency or the generals? And has the structure of power changed dramatically over short periods of time despite there being no change in the legal basis for the allocation of power? Without very detailed knowledge, perhaps the best that can be done is to infer the political structure from the behavior (e.g., the age of the chosen leader). But even here, more detail will need to be known before proper inferences can be made.

${ }^{38}$ I would like to thank Yoram Barzel for suggesting the comparison. 


\section{APPENDIX A}

\section{THE N-VOTER CASE}

To reduce needless complications, I assume that $w=1$ and $K_{c}$ is the same for all individuals.

Proposition 1A: If and only if $\mathrm{M}$ prefers a candidate over all other candidates will a majority of voters prefer that candidate over all other candidates.

\section{Proof:}

Consider an arbitrary pair of voters L and R such that L's most preferred position is to the left of M's most preferred position and R's most preferred position is to the right. For convenience, let M's most preferred position on policy be 0 , L's most preferred position on policy be $L<0$, and R's most preferred position on policy be $R>0$. All three voters agree on the optimal age, $a^{\Omega}$. That is what is meant by a valence characteristic. We will not consider leadership valence. The proof will make it clear that adding leadership valence will not change the results of the proposition, but will make the statements longer.

The proof is by contradiction. Let ( $\mathrm{x}^{*}, a^{*}$ ) be the individual, called Star (with policy $\mathrm{x}^{*}$ and age $\left.a^{*}\right)$, who is most preferred by $\mathrm{M}$. I show below that if $\mathrm{L}$ and $\mathrm{R}$ both strictly prefer some individual, called Number (with policy and age, $\mathrm{x}, a \#)$ to $\left(\mathrm{x}^{*}, a^{*}\right)$, then $\mathrm{M}$ will strictly prefer $(\mathrm{x} \#, a \#)$ to $\left(\mathrm{x}^{*}, y^{*}\right)$, also. But this contradicts the statement that $\mathrm{M}$ strictly prefers Star. Hence if and only if M prefers an individual to all other individuals will a majority of voters prefer the same individual to everyone else.

There are a number of possible combinations (no one was elected previously, everyone was elected previously, some were elected previously and others were not). ${ }^{39} \mathrm{I}$ consider only two possibilities here, but the methodology is the same in each case. I start with the logically easiest case.

${ }^{39}$ Not all of these are possible when the leader is elected for life. 


\section{Both candidates have served as leader previously}

Since utility is written as a loss function. I ignore all the minus signs and find the smallest positive number rather than the most negative number.

(A1) $(L-\mathrm{x} \#)^{2}+(\hat{a}-a \#)^{2}<\left(L-\mathrm{x}^{*}\right)^{2}+\left(\hat{a}-a^{*}\right)^{2}$. Equivalently,

$(L-\mathrm{x} \#)^{2}-\left(L-\mathrm{x}^{*}\right)^{2}<\left(\hat{a}-a^{*}\right)^{2}-(\hat{a}-a \#)^{2}$. Equivalently,

$2 L\left[\mathrm{x}^{*}-\mathrm{x} \#\right]<\left(\hat{a}-a^{*}\right)^{2}-(\hat{a}-a \#)^{2}+\left(\mathrm{x}^{*}\right)^{2}-(\mathrm{x} \#)^{2}$

(A2) $(R-\mathrm{x} \#)^{2}+(\hat{a}-\mathrm{y} \#)^{2}<\left(R-\mathrm{x}^{*}\right)^{2}+\left(\hat{a}-\mathrm{a}^{*}\right)^{2}$. Equivalently,

$(R-\mathrm{x} \#)^{2}-\left(R-\mathrm{x}^{*}\right)^{2}<\left(\hat{a}-a^{*}\right)^{2}-(\hat{a}-a \#)^{2}$. Equivalently,

$2 R[\mathrm{x} *-\mathrm{x} \#]<\left(\hat{a}-a^{*}\right)^{2}-(\hat{a}-a \#)^{2}+(\mathrm{x} *)^{2}-(\mathrm{x} \#)^{2}$

(A3) $(0-\mathrm{x} \#)^{2}+(\hat{a}-a \#)^{2}>\left(0-\mathrm{x}^{*}\right)^{2}+\left(\hat{a}-a^{*}\right)^{2}$. Equivalently,

$(0-\mathrm{x} \#)^{2}-\left(0-\mathrm{x}^{*}\right)^{2}>\left(\hat{a}-a^{*}\right)^{2}-(\hat{a}-a \#)^{2}$. Equivalently,

$2[0][\mathrm{x} *-\mathrm{x} \#]>\left(\hat{a}-a^{*}\right)^{2}-(\hat{a}-a \#)^{2}+(\mathrm{x} *)^{2}-(\mathrm{x} \#)^{2}$

$L<0$ and $R>0$. Therefore $2 L\left[\mathrm{x}^{*}-\mathrm{x} \#\right]$ and $2 R\left[\mathrm{x}^{*}-\mathrm{x} \#\right]$ are of opposite signs (for $\left.\mathrm{x}^{*} \neq \mathrm{x}^{*}\right)$. The positive expression must be larger than the left-hand side of the last inequality in (A3) which is 0. But in (A3) the left-hand side is greater than the right-hand side while in (A1 and (A2) the opposite is the case. Therefore, there is a contradiction. ///

Before going on, notice that all the valence terms are on the right-hand side of the inequalities and are the same for everyone. So adding more valence issues does not change the proof. 


\section{M prefers previously elected Star to all other individuals, none having been elected to office previously. That is, $\varepsilon^{*}=0$ and $\varepsilon \#=\varepsilon>0 .^{40}$}

(A4) $.5[1-Q](L-\mathrm{x} \#-\varepsilon)^{2}+.5[1-Q](L-\mathrm{x} \#+\varepsilon)^{2}+Q(L-\mathrm{x} \#)^{2}+(\hat{a}-a \#)^{2}<\left(L-\mathrm{x}^{*}\right)^{2}+\left(\hat{a}-a^{*}\right)^{2}$.

Equivalently,

$$
.5[1-Q](L-\mathrm{x} \#-\varepsilon)^{2}+.5[1-Q](L-\mathrm{x} \#+\varepsilon)^{2}+Q(L-\mathrm{x} \#)^{2}-\left(L-\mathrm{x}^{*}\right)^{2}<(\hat{a}-\mathrm{y} *)^{2}-(\hat{a}-\mathrm{y} \#)^{2} .
$$

Equivalently,

$$
\begin{aligned}
& .5[1-Q]\left[L^{2}+(\mathrm{x} \#)^{2}+\varepsilon^{2}-2 L \mathrm{x} \#-2 L \varepsilon+2 \mathrm{x} \# \varepsilon\right]+.5[1-Q]\left[L^{2}+(\mathrm{x} \#)^{2}+\varepsilon^{2}-2 L \mathrm{x} \#+2 L \varepsilon-2 \mathrm{x} \# \varepsilon\right] \\
& +Q\left[L^{2}+(\mathrm{x} \#)^{2}-2 L \mathrm{x} \#\right]-\left[L^{2}+\left(\mathrm{x}^{*}\right)^{2}-2 L \mathrm{x} *\right]<\left(\hat{a}-a^{*}\right)^{2}-(\hat{a}-a \#)^{2}
\end{aligned}
$$

Equivalently,

$$
-2 L \mathrm{x} \#+2 L \mathrm{x}^{*}=2 L[\mathrm{x} * \mathrm{x} \#]<-[1-Q] \varepsilon^{2}+\left(\mathrm{x}^{*}\right)^{2}-(\mathrm{x} \#)^{2}+\left(\hat{a}-a^{*}\right)^{2}-(\hat{a}-a \#)^{2}
$$

Via a similar process for $\mathrm{R}$ and $\mathrm{M}$, we get the following:

(A5) $2 R\left[\mathrm{x}^{*}-\mathrm{x} \#\right]<-[1-Q] \varepsilon^{2}+\left(\mathrm{x}^{*}\right)^{2}-(\mathrm{x} \#)^{2}+\left(\hat{a}-a^{*}\right)^{2}-(\hat{a}-a \#)^{2}$

(A6) $2 M[\mathrm{x} *-\mathrm{x} \#]=0>-[1-Q] \varepsilon^{2}+\left(\mathrm{x}^{*}\right)^{2}-(\mathrm{x} \#)^{2}+\left(\hat{a}-a^{*}\right)^{2}-(\hat{a}-a \#)^{2}$

The left-hand sides of (A4) and (A5) have opposite signs. So both cannot be less than zero. The value of the left-hand side of (A6) is greater than the right-hand side, while the left-hand sides of (A4) and (A5) are less than the right-hand side. Once again there is a contradiction. ///

\footnotetext{
40 Another way of saying this is that $\mathrm{x}^{*}$ in this election is equal to the $\mathrm{x}^{*}$ before the incumbent was elected plus the $\varepsilon$ that was revealed during the first term in office.
} 


\section{APPENDIX B}

\section{K-COHORTS}

Proposition $1 B$. The median voter in the $(\mathrm{k}+1) / 2$ cohort will be the median voter overall.

Proof: The median voter in each cohort has the same preference regarding policy. The preferences of the median voters only differ on the valence characteristic, age. By assumption, the median-aged cohort has the median preference on age. Looking at the median voters alone, the most preferred candidate of the median of medians will be the most preferred candidate by a majority of these median voters. That is, there is truly a median voter when looking only at the selected median voter from each cohort (we have just relabeled the axes in Figure 1 to account for the median voters' preferences). And as before, whatever candidate the median of a cohort most desires is the most desired candidate of a majority of voters in that cohort. Since all cohorts are the same size, the median voter in the $(k+1) / 2$ cohort, will be the overall median voter over all cohorts and voters. /// 


\section{APPENDIX C}

\section{OTHER SOLUTION CONCEPTS}

In this appendix, I specify a voting procedure and relate it to the literature on voting.

(C1) A candidate wins the election if the candidate receives a majority of votes in all pairwise contests.

In reality, all pair-wise elections need not be undertaken if the outcome can be predicted.

(C2) Each voter is a potential candidate with the same set of preferences as in his/her capacity as a voter.

I have already shown that the candidate most preferred by the median voter will be preferred by a majority of voters to any other candidate. So there is indeed a Condorcet winner.

It is useful to compare this model to previous work. As is the case here, Besley and Coate (1997) assume that candidates will follow their own preferences once in office. However, unlike the present paper, they assume that individuals choose whether to be candidates. Here, the elected leader is the person closest to the median voter. In their model, the person closest to the median voter need not be a candidate and therefore the closest person to the median voter need be elected.

There is a large literature on valence characteristics combined with a uni-dimensional policy space. This literature allows the candidates to freely choose a policy position. As a consequence, there is no pure-strategy equilibrium as the person with the higher valence wants to choose an equivalent policy to the person with a lower valence (thereby gaining all the votes), while the person with a lower valence wants to be sufficiently far away on the policy dimension to garner at least some votes (see Groseclose, 2001). In the present paper, the candidate cannot credibly commit to any policy that differs from a weighted average of her own and the median voter's preference and as a consequence a pure-strategy equilibrium exists.

I would suggest that the approach used here is better for explaining elections of pope and patriarch and that the other approaches mentioned in this appendix are better for explaining elections to congress and city councils, for example. 


\section{REFERENCES}

Allen, Douglas W. (1995) "Order in the church: a property rights approach". Journal of Economic Behavior and Organization 27: 97-117.

Ansolobehere, S. and J. Snyder (2000) "Valence politics and equilibrium in spatial models". Public Choice 103: 327-336.

Baumgartner, Frederic J. (2003) Behind Locked Doors: A History of the Papal Elections. New York: Palgrave Macmillan.

Downs, Anthony (1957) An Economic Theory of Democracy. New York: Harper and Row.

Enelow, J. M. and M. Hinich (1982) "Nonspatial candidate characteristics and electoral competition". Journal of Politics 44:115-130.

Finke, Roger (1997) "The Consequences of Religious Competition: Supply-side Explanations for Religious Change." In Lawrence A. Young (ed.), Rational Choice Theory and Religion, New York: Routledge Press

Giuriato, Luisa (2009) "Combining autocracy and majority voting: The canonical succession rules of the Latin Church". In Ferrero, Mario and Ronald Wintrobe (eds) The Political Economy of Theocracy. New York: Palgrave McMillan.

Groseclose, Tim. (2001) "A Model of Candidate Location When One Candidate Has a Valence Advantage". American Journal of Political Science. 45: 862-86

Hummel, Patrick (2010) "On the Nature of Equilibria in a Downsian Model with Candidate Valence". Games and Economic Behavior 70: 425-445.

Iannaccone, Laurence (1988)) "A formal model of church and sect". American Journal of Sociology 94:241-268. 
Jensen, Michael and William Meckling (1976) "Theory of the firm: Mangerial behavior, agency costs and ownership structure". Journal of Financial Economics 3: 305-360.

Mao, Wen and Zech, Charles (2002) "Choices of organizational structures in religious organizations: a game theoretic approach". Journal of Economic Behavior \& Organization 47: $55-70$.

Norbu, Thubten Jigme and Turnbull, Colin M. (1968) Tibet: An account of the history, the religion and the people of Tibet. Reprint. New York: Touchstone Books.

Penton, James M. (1985) Apocalypse Delayed: The Story of the Jehovah's Witnesses. Toronto: University of Toronto Press.

Pham, John-Peter (2004) Heirs of the Fisherman: Behind the Scenes of Papal Death and Succession. Oxford: Oxford University Press.

Reese, Thomas J. (1996) Inside the Vatican: The Politics and the Organization of the Catholic Church. Cambridge: Harvard University Press.

Stokes, Donald, 1992. "Valence politics". In D. Kavenagh (ed.) Electoral Politics. Oxford: Clarendon Press.

Tullock, Gordon (1987) Autocracy. Boston: Kluwer.

Weber, Max (1922, 1993) The Sociology of Religion. Boston: Beacon Press.

Wilde, Melissa J., Kristin Geraty, Shelley Nelson and Emily Bowman (2010) "Religious Economy or Organizational Field? Predicting Bishops’ Votes at the Second Vatican Council.” American Sociological Review. 75(4): 586-606.

Wintrobe, Ronald (1998) The Political Economy of Dictatorship. New York: Cambridge University Press.

Young, Lawrence A. (1997) Rational Choice Theory and Religion, (ed.), New York: Routledge Press 